\title{
ЗВ'ЯЗОК ХІМІЧНИХ ТА ФІЗИЧНИХ ПОКАЗНИКІВ ВОДИ 3 МОРФОЛОГІЧНИМИ ОЗНАКАМИ РАКІВ РІЗНИХ ВИДІВ
}

\author{
Федорович Єлизавета Іллівна \\ доктор сільськогосподарських наук, професор \\ Інститут біології тварин НААН \\ ORCID 0000-0002-9910-7902 \\ Муженко Андрій Володимирович \\ аспірант \\ Інститут розведення і генетики тварин імені М. В. Зубця НАAН \\ ORCID 0000-0003-1032-7317 \\ Слюсар Микола Вікторович \\ кандидат сільськогосподарських наук, \\ Поліський національний університет \\ ORCID: 0000-0002-3668-2109
}

\begin{abstract}
Об'єктом досліджень була галузь аквакультури, а саме технологія вирощування раків в умовах замкнутого водопостачання. Були проведені дослідження по впливу температури, насичення кисню та кислотності води на морфологічні ознаки раків. Метою досліджень було визначення оптимального рівня кисню, температури та кислотності середовища, при якій спостерігаються найбільші прирости та найменші втрати поголів'я. Технологія промислового вирощування раків ще недостатньо розвинута. Вирощування товарного раку з визначенням оптимального рівню кисню є найважливішим елементом цієї технології. Вплив вмісту кисню при вирощуванні гідробіонтів має першочергове значення. При цьому рівень кисню тісно пов'язаний з температурою в установці замкнутого водопостачання. Зміна температурного режиму в допустимих межах не викликають значні зміни в процесі розвитку раків, проте, підвищення температури відповідно збільшує споживання кисню та активізує інші процеси метаболізму. Провівши дослідження отримано наступні результати: найкращою температурою для утримання всіх видів раків є 23-25ㄷ. 3 міна кислотності в межах 6-8 ${ }^{\circ} \mathrm{T}$ не впливала на збільшення живої маси ракоподібних. Зміна апетиту, поведінки та приростів не спостерігалася в жодній групі. При зниженні рівня кисню до 5 мг/л. спостерігалося пригнічення апетиту та зменшення рухливості раків червоноклешневого виду, а на кінець другої доби 75\% раків загинуло. У річкового широкопалого рака також було помічено кисневе голодування. Найкраще переніс зниження рівня кисню мармуровий рак, у якого спостерігалося не значне зменшенням приростів. Несприятливі умови кисневого середовища спровокували порівняно високу смертність особин. В кінцевому підсумку все це призвело до мінімальної біопродуктивності.
\end{abstract}

Ключові слова: раки, австралійський червоноклешневий, широкопалий, мармуровий, хімічні показники води, аквакультура, гідробіонти.

DOI: https://doi.org/10.32845/bsnau.Ivst.2021.4.28

Австралійський червоноклешневий рак (Cherax quadricarinatus) має цінні господарськи корисні ознаки і $€$ перспективним об'єктом для вирощування. Цей вид характеризується високою швидкістю росту, невибагливістю до умов утримання, а найголовніше - відносно низькими показниками агресивності і прояви канібалізму. У природі ці раки поширені в прісних водоймах на півночі австралійського континенту. Довжина тіла раків може досягати 20 - 25 см. Жива маса самців - до 550 г, самок - до 430 г. Статевої зрілості вони досягають у віці 6 - 8 міс. при розмірі тіла близько 8 - 10 см. [1].

Широкопалий рак (Astacus astacus) поширений у деяких невеличких річках і озерах правобережної заплави Дністра, Пруту й Тетерева; має природоохоронний статус вразливий. Чисельність виду незначна. Причини зміни чисельності: різні прояви антропогенного впливу - евтрофрікація, збіднення води на кисень, забруднення річок пестицидами, замулення тощо, а також пряме знищення людиною. Може розмножуватися в неволі, але в Україні вид не розводять. У кліматичних умовах України довгопалий рак стає статевозрілим здебільшого на третьому році життя при довжині тіла 8-9 см. Жива маса самців - до 200 г., самок - до 150 г. [11].

Мармуровий рак (Procarambus virginalis) це прісноводний вид раків, який завдяки партеногенетичному способу розмноження займає унікальне місце серед десятиногих ракоподібних. Мармурові раки $€$ нащадками раків Procambarus fallax, що розмножуються статевим шляхом. Поширення через торгівлю домашніми тваринами та антропогенні викиди призвели до збільшення кількості диких популяцій у кількох країнах. Розмноженню мармурових раків сприяє їх партеногенетичний спосіб розмноження та висока плодючість, що дозволяє створити великі популяції з окремих тварин і може служити моделлю для поширення інвазійних видів. Однак наше розуміння поширення мармурових раків, походження, диверсифікації та здатності пристосовуватися до нового середовища суттєво обмежене браком генетичної інформації [12].

Технологія промислового вирощування раків ще недостатньо розвинута. Найважливішим елементом цієї технології $€$ вирощування молодняку з визначенням оптимального рівню кисню в установках замкнутого водопостачання (У3B).

Тому вплив кисневого фактора при вирощуванні гідробіонтів має першочергове значення. При цьому рівень 
кисню тісно пов'язаний з температурним режимом у водному середовищі.

Підвищення або зниження температури в допустимих межах викликають відповідні зміни в процесі життєдіяльності раків. Проте, підвищення температури збільшує споживання кисню, екскрецію амонійного азоту, активізує інші процеси метаболізму, підсилює пошук, споживання, засвоєння їжі, прискорює всмоктування розчинених речовин з навколишнього середовища, підвищує чутливість до токсикантів, прискорює розвиток і статеве дозрівання. Відомо, що летальною для австралійського червоноклешневого раку $€$ температура нижче $10^{\circ} \mathrm{C}$ і вище $36^{\circ} \mathrm{C}$ [2]. При цьому деякі автори вказують температуру для конфортного вирощування раків в діапазоні $25-30^{\circ} \mathrm{C}[3,4]$.

Потреби в кисню можуть бути виражені у вигляді питомого споживання О2 (кількість кисню, яка споживається 1 кг гідробіонтів при певній температурі вирощування в одиницю часу - наприклад, мг/кг на годину) [6]. Цей показник визначається інтенсивністю обмінних процесів в організмі ракоподібних в залежності від впливу факторів навколишнього середовища. Кисень гірше розчиняється в теплій воді, тому при розведенні австралійського червоноклешневого рака, в штучних умовах фрактор достатньої наявності кисню в воді $€$ одним з визначальних технологічних показників експлуатації УЗВ. Саме тому цей взаємозв'язок між біологічними процесами привів нас до комплексного вивчення температурного режиму, рівня кисню, кислотності води в процесі відпрацювання технології вирощування в умовах установок замкнутого водопостачання. 3 точки зору постійного вирощування товарної продукції, незалежно від кліматичної зони аквакультури, найбільш цікавим є варіант культивування цих раків в установках із замкнутим водопостачанням. Вирощування гідробіонтів в таких установках надає температурному фактору особливе значення, так як він $€$ повністю керованим параметром штучної екосистеми. Це в свою чергу дозволяє впливати на життєві функції раків і обмінні процеси їх організму, які пов'язані з кількістю спожитого кисню.

Гідробіонти (в тому числі раки) дихають розчиненим у воді киснем через зябра, тому зміст його у воді має для них першорядне значення. Кисневі потреби ракоподібних детально розглянуті в класичній праці Л.М. Сущені. [5].

Рівень кисню відіграє важливу роль в процесі життєдіяльності всіх живих організмів. Він є невід'ємною частиною всіх окисних процесів як наземних організмів так і мешканців водного масиву [10]. Саме для створення достатнього рівня кисню та створення сприятливої мікрофрлори у воді, та очищення її від продуктів життєдіяльності гідробіонтів використовують установки замкнутого водопостачання [7].

В установках замкнутого водопостачання насичення киснем відбувається аераторами. Це важливо при великій щільності посадки гідробіонтів, так як концентрація кисню може знижуватися до критичних значень. Особливо це небезпечно для раків, так як зі зниженням температури кількість розчинених газів збільшується. Залежність концентрації кисню у воді до температури наведена у табл.1.

Таблиця 1

Концентрація кисню у воді відповідно до температури [9].

\begin{tabular}{|c|c|c|}
\hline Температура води, ${ }^{\circ} \mathrm{C}$ & Максимально допустима концентрація кисню у воді, мг/л & Мінімально допустима концентрація кисню у воді, мг/л \\
\hline 10 & 12,0 & 8,8 \\
\hline 15 & 10,3 & 8,3 \\
\hline 20 & 9,3 & 7,8 \\
\hline 25 & 8,3 & 7,4 \\
\hline 30 & 7,6 & 6,9 \\
\hline
\end{tabular}

При підвищенні температури, вода у басейні здатна розчинити в собі меншу кількість кисню. У таких випадках потрібно підтримувати вміст кисню не нижче 7 мг/л. У таблиці також наведені приблизні значення мінімально допустимої концентрації кисню. Це усереднені цифри, які потрібно коригувати в залежності від виду гідробіонтів, що вирощуються в установці. Так як дрібні види споживають більше кисню в перерахунку на одиницю маси тіла. При зниженні вмісту $\mathrm{O}_{2}$ в воді у живих організмів починаються ознаки кисневого голодування, які можуть привести до задухи та загибелі. У той же час деякі види можуть жити у водах з екстремально низьким вмістом кисню, наприклад соми, за рахунок здатності особливого кишкового дихання [8].

Метою досліджень було визначення оптимального рівня кисню середовища, при якій найкращим чином поєднуються швидкість росту, збереженість та інші показники вирощування австралійських червоноклешневих раків.

Матеріали та методи досліджень. Дослід проводився в лабораторії аквакультури Поліського національного університету (Житомирська обл., м. Житомир, вул. Корольова 39 В.).

Для експерименту були відібрані статевозрілі особи австралійського червоноклешневого, мармурового та широ- копалого річкового раків. Піддослідні раки містилися в установці для утримання гідробіотів. Кожна ємність об'ємом 150 л 3 автономною системою очищення, і регуляцією температури та кисню, постійною підміною води (рис. 1).

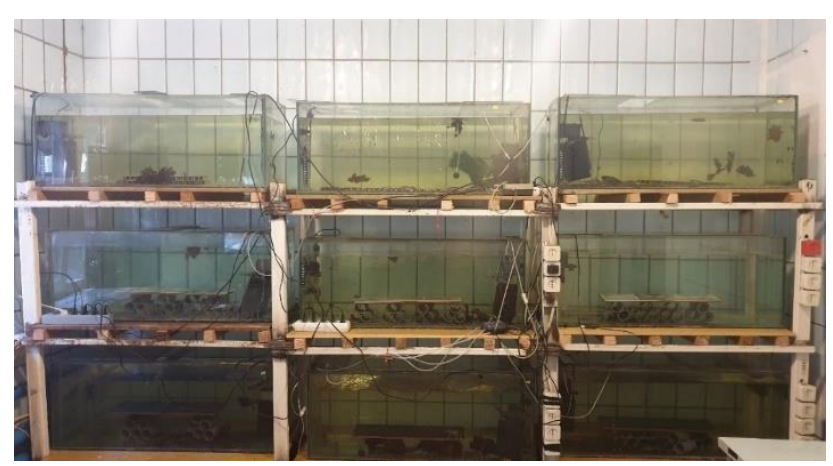

Рис. 1. Експериментальні акваріуми з раками

Всіх раків було поділено на три групи, кожна з яких складалися з трьох гнізд (3 самки, 1 самець) кожного виду (австралійського червоноклешневого, мармурового та річкового широкопалого) (рис. 2). 


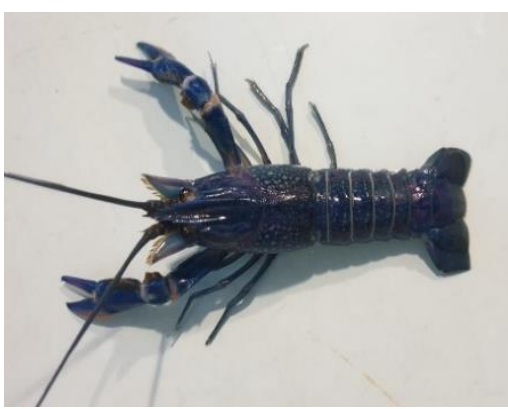

a

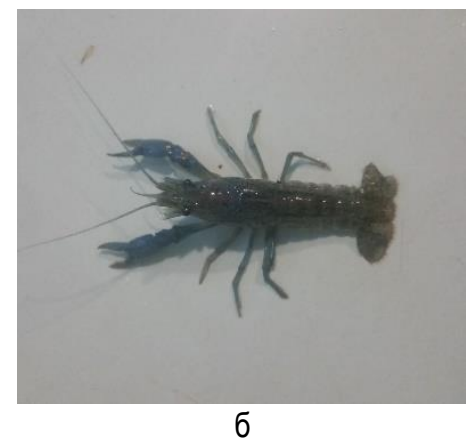

Рис. 2. Піддослідні види раків

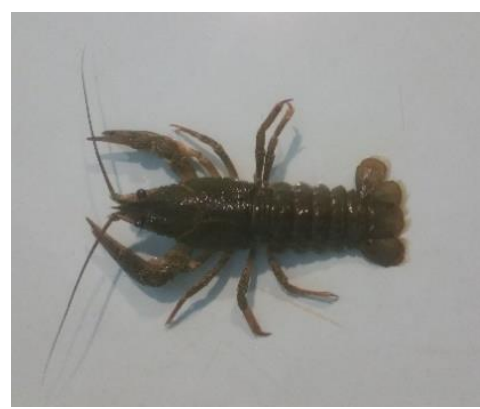

B

a - австраліський червоноклешневий; б -мармуровий; в - річковий широкопалий

Дослід проводився на протязі п'ятнадцяти діб при $\mid$ температура підтримувалася на рівні $23^{\circ} \mathrm{C}$, на протязі 6-10 рівні $\mathrm{pH} 7^{\circ} \mathrm{T}$, рівні насичення киснем 7 мл./л. Перших 5 діб $\quad$ днів $-20^{\circ} \mathrm{C}$, протягом $11-15$ днів - 17 ${ }^{\circ} \mathrm{C}$ (табл. 2.).

Таблиця 2.

\section{Схема досліду №1}

\begin{tabular}{|l|c|c|c|}
\hline \multicolumn{1}{|c|}{ Вид раків } & Температура, ${ }^{\circ}$ C. $1-5$ днів & Температура, ${ }^{\circ}$ C. $6-10$ днів & Tемпература, ${ }^{\circ}$ C. $11-15$ днів \\
\hline Австралійський червоноклешневий (1група) & 23 & 20 & 17 \\
\hline Мармуровий (2 група) & 23 & 20 & 17 \\
\hline Річковий широкопалий (3 група) & 23 & 20 & 17 \\
\hline
\end{tabular}

Суттєвих змін у поведінці та параметрах розвитку кубинських та річкових раків на протязі проведення досліду не виявлено, проте австралійські червоноклешневі раки при температурі води $17^{\circ} \mathrm{C}$, стали менш рухливими, спостерігалося погіршення апетиту вже з другої доби досліду.

Для наступного досліду рівень Рн у перший період досліду (5 днів) за допомогою додавання бікарбонату натрію був знижений до рівня $6^{\circ}$ Т, у другий період (6-10 день) залишився на рівні $7^{\circ} \mathrm{T}$, у завершальний період (11-15 день) за допомогою додавання оцтової кислоти був підвищений до $8^{\circ}$ Т. Дослід тривав 15 діб при температурі води $25^{\circ} \mathrm{C}$, та рівні насичення киснем 7 мл/л. Кислотність вимірювали за допомогою лакмусових смужок для визначення рівня $\mathrm{pH}$. (табл. 3.).

Таблиця 3.

Схема досліду №2

\begin{tabular}{|c|c|c|c|}
\hline Вид раків & Кислотність води, ${ }^{\circ}$ T. 1-5 днів & Кислотність води, ${ }^{\circ}$ Т. 6-10 днів & Кислотність води, ${ }^{\circ}$ Т. 11-15 днів \\
\hline Австралійський червоноклешневий (1група) & 8 & 7 & 6 \\
\hline Мармуровий (2 група) & 8 & 7 & 6 \\
\hline Річковий широкопалий (3 група) & 8 & 7 & 6 \\
\hline
\end{tabular}

Зміна поведінки, пригнічення апетиту та приростів у всіх трьох групах не спостерігалася. Це дає змогу зробити висновок що коливання кислотності в межах 6-8 ${ }^{\circ} \mathrm{T}$ не впливає на розвиток ракоподібних.

Для наступного досліду рівень кисню в перший пері- од за допомогою аератора був доведений до 8 мг/л (робочий рівень кисню), у другій період до 6 мл/л, у третій до 5 мл/л. Дослід тривав 15 днів при температурі $25^{\circ} \mathrm{C}$, та кислотності $7^{\circ}$ Т. Аналіз води проводили щодня для кожної групи по 5 діб. (табл. 4.)

Таблиця 4.

\section{Схема досліду №3}

\begin{tabular}{|c|c|c|c|}
\hline Вид раків & Рівень кисню, мг/л. 1-5 днів & Рівень кисню, мг/л. 6-10 днів & Рівень кисню, мг/л. 11-15 днів \\
\hline Австралійський червоноклешневий (1група) & 8 & 6 & 5 \\
\hline Мармуровий (2 група) & 8 & 6 & 5 \\
\hline Річковий широкопалий (3 група) & 8 & 6 & 5 \\
\hline
\end{tabular}

Насичення киснем відбувалося за допомогою аераторів. Визначення вмісту кисню у воді проводили крапельним методом, реагентами Tetra «Test $\mathrm{O}_{2}$ » (рис. 3.)

Вирощування раків при температурі $20^{\circ} \mathrm{C}$ показав добру питому швидкість росту, середньодобовий приріст, витрати корму і рівень канібалізму, в співвідношенні з показниками при температурі води $23^{\circ} \mathrm{C}$. ЖМ червоноклешневого збільшувалась на 2,07 г, річкового - 0,2 г, мармурового 0,21 г. При цьому можна відзначити, що при такому температурному режимі менші енергозатрати (табл. 5).

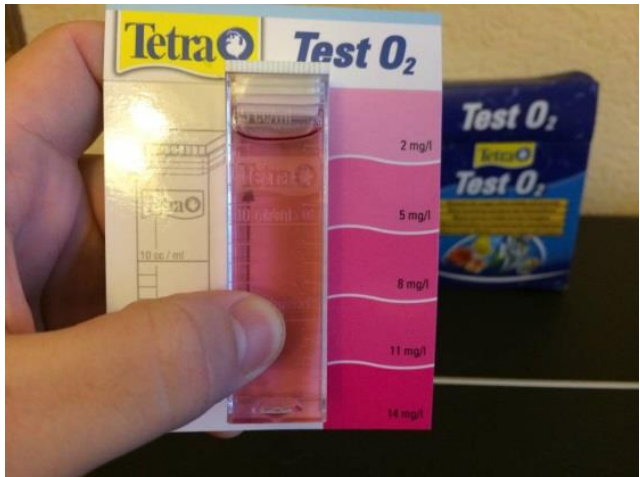

Рис. 3. Процес визначення вмісту кисню у воді. 
Таблиця 5.

Вплив температури води на динаміку росту живої маси ракоподібних різних видів

\begin{tabular}{|c|c|c|c|c|c|c|c|c|c|}
\hline \multirow{4}{*}{ Період досліду } & \multicolumn{9}{|c|}{ Вид раків } \\
\hline & \multicolumn{3}{|c|}{ Червоноклешневий } & \multicolumn{3}{|c|}{ Широкопалий } & \multicolumn{3}{|c|}{ Мармуровий } \\
\hline & \multicolumn{9}{|c|}{ температура води $23{ }^{\circ} \mathrm{C}$. } \\
\hline & $\mathrm{n}$ & $M \pm m, r$ & $\mathrm{C}_{\mathrm{v},} \%$ & $\mathrm{n}$ & $M \pm m, r$ & $\mathrm{C}_{\mathrm{v},} \%$ & $\mathrm{n}$ & $M \pm m, r$ & $\mathrm{C}_{\mathrm{v}}, \%$ \\
\hline Перший день & 12 & $67,12 \pm 1,13$ & 14 & 12 & $49,39 \pm 0,58$ & 9,8 & 12 & $21,50 \pm 0,17$ & 6,6 \\
\hline Другий день & 12 & $67,57 \pm 1,12$ & 13,9 & 12 & $49,41 \pm 0,58$ & 9,8 & 12 & $21,55 \pm 0,17$ & 6,5 \\
\hline Третій день & 12 & $68,05 \pm 1,13$ & 13,9 & 12 & $49,45 \pm 0,58$ & 9,8 & 12 & $21,59 \pm 0,17$ & 6,5 \\
\hline Четвертий день & 12 & $68,57 \pm 1,13$ & 13,8 & 12 & $49,59 \pm 0,57$ & 9,7 & 12 & $21,64 \pm 0,17$ & 6,5 \\
\hline \multirow[t]{2}{*}{ П'ятий день } & 12 & $69,02 \pm 1,14$ & 13,8 & 12 & $49,63 \pm 0,58$ & 9,7 & 12 & $21,70 \pm 0,16$ & 6,4 \\
\hline & \multicolumn{9}{|c|}{ температура води $20^{\circ} \mathrm{C}$. } \\
\hline Перший день & 12 & $69,02 \pm 1,14$ & 13,8 & 12 & $49,63 \pm 0,58$ & 9,7 & 12 & $21,70 \pm 0,16$ & 6,4 \\
\hline Другий день & 12 & $69,53 \pm 1,14$ & 13,7 & 12 & $49,67 \pm 0,57$ & 9,7 & 12 & $21,75 \pm 0,17$ & 6,4 \\
\hline Третій день & 12 & $70,01 \pm 1,15$ & 13,6 & 12 & $49,72 \pm 0,58$ & 9,7 & 12 & $21,79 \pm 0,17$ & 6,4 \\
\hline Четвертий день & 12 & $70,47 \pm 1,15$ & 13,7 & 12 & $49,76 \pm 0,58$ & 9,7 & 12 & $21,85 \pm 0,17$ & 6,4 \\
\hline \multirow[t]{2}{*}{ П'ятий день } & 12 & $71,09 \pm 1,16$ & 13,6 & 12 & $49,83 \pm 0,57$ & 9,7 & 12 & $21,91 \pm 0,17$ & 6,3 \\
\hline & \multicolumn{9}{|c|}{ температура води $17^{\circ} \mathrm{C}$. } \\
\hline Перший день & 12 & $71,09 \pm 1,16$ & 13,6 & 12 & $49,83 \pm 0,57$ & 9,7 & 12 & $21,91 \pm 0,17$ & 6,3 \\
\hline Другий день & 12 & $71,48 \pm 1,15$ & 13,4 & 12 & $49,86 \pm 0,58$ & 9,7 & 12 & $21,96 \pm 0,17$ & 6,3 \\
\hline Третій день & 12 & $71,94 \pm 1,16$ & 13,5 & 12 & $49,90 \pm 0,58$ & 9,6 & 12 & $22,00 \pm 0,17$ & 6,3 \\
\hline Четвертий день & 12 & $72,35 \pm 1,17$ & 13,5 & 12 & $49,94 \pm 0,58$ & 9,6 & 12 & $22,04 \pm 0,17$ & 6,4 \\
\hline П'ятий день & 12 & $72,78 \pm 1,17$ & 13,5 & 12 & $50,00 \pm 0,58$ & 9,7 & 12 & $22,10 \pm 0,17$ & 6,4 \\
\hline
\end{tabular}

Порівняно низькі результати вирощування відзначені в останньому варіанті досліду при температурі води $17^{\circ}$ С. Раки росли помітно повільніше, а саме червоноклешневий, ніж в інших варіантах досліду, було помітне значне зниження апетиту у раків австралійського виду, але широкопалий та мармуровий - зміни не помітні. Жива маса становила 1,69 г, 0,17 г, 0,19 г.

\section{Вплив рівня кисню на динаміку росту живої маси ракоподібних різних видів}

Таблиця 6.

\begin{tabular}{|c|c|c|c|c|c|c|c|c|c|}
\hline \multirow{4}{*}{ Період досліду } & \multicolumn{9}{|c|}{ Вид раків } \\
\hline & \multicolumn{3}{|c|}{ Червоноклешневий } & \multicolumn{3}{|c|}{ Широкопалий } & \multicolumn{3}{|c|}{ Мармуровий } \\
\hline & \multicolumn{9}{|c|}{ Інтенсивність насичення киснем 8 мг/л. } \\
\hline & $\mathrm{n}$ & $\mathrm{M} \pm \mathrm{m}, \mathrm{r}$ & $\mathrm{C}_{\mathrm{v},} \%$ & $\mathrm{n}$ & $\mathrm{M} \pm \mathrm{m}, \mathrm{r}$ & $\mathrm{C}_{\mathrm{v},} \%$ & $\mathrm{n}$ & $\mathrm{M} \pm \mathrm{m}, \mathrm{r}$ & $\mathrm{C}_{\mathrm{v},}, \%$ \\
\hline Перший день & 12 & $66,89 \pm 1,13$ & 14,2 & 12 & $49,79 \pm 0,61$ & 10,3 & 12 & $21,51 \pm 0,14$ & 5,5 \\
\hline Другий день & 12 & $67,31 \pm 1,13$ & 14,1 & 12 & $49,84 \pm 0,61$ & 10,2 & 12 & $21,57 \pm 0,14$ & 5,4 \\
\hline Третій день & 12 & $67,72 \pm 1,14$ & 14,3 & 12 & $49,88 \pm 0,60$ & 10,2 & 12 & $21,61 \pm 0,14$ & 5,4 \\
\hline Четвертий день & 12 & $68,16 \pm 1,16$ & 14,3 & 12 & $49,94 \pm 0,60$ & 10,2 & 12 & $21,65 \pm 0,14$ & 5,4 \\
\hline \multirow[t]{2}{*}{ П'ятий день } & 12 & $68,56 \pm 1,16$ & 14,3 & 12 & $50,01 \pm 0,61$ & 10,2 & 12 & $21,69 \pm 0,14$ & 5,5 \\
\hline & \multicolumn{9}{|c|}{ Інтенсивність насичення киснем 6 мг/л. } \\
\hline Перший день & 12 & $68,56 \pm 1,16$ & 14,3 & 12 & $50,01 \pm 0,61$ & 10,2 & 12 & $21,69 \pm 0,14$ & 5,5 \\
\hline Другий день & 12 & $69,09 \pm 1,17$ & 14,2 & 12 & $50,07 \pm 0,61$ & 10,2 & 12 & $21,73 \pm 0,14$ & 5,4 \\
\hline Третій день & 12 & $69,46 \pm 1,17$ & 14,1 & 12 & $50,13 \pm 0,60$ & 10,2 & 12 & $21,77 \pm 0,14$ & 5,4 \\
\hline Четвертий день & 12 & $69,83 \pm 1,18$ & 14,1 & 12 & $50,18 \pm 0,60$ & 10,2 & 12 & $21,82 \pm 0,14$ & 5,4 \\
\hline \multirow[t]{2}{*}{ П'ятий день } & 12 & $70,25 \pm 1,18$ & 14,1 & 12 & $50,24 \pm 0,61$ & 10,1 & 12 & $21,88 \pm 0,14$ & 5,4 \\
\hline & \multicolumn{9}{|c|}{ Інтенсивність насичення киснем 5 мг/л. } \\
\hline Перший день & 12 & $70,25 \pm 1,18$ & 14,1 & 12 & $50,24 \pm 0,61$ & 10,2 & 12 & $21,88 \pm 0,13$ & 4,8 \\
\hline Другий день & 9 & $70,28 \pm 1,18$ & 14,1 & 12 & $50,27 \pm 0,62$ & 10,2 & 12 & $21,92 \pm 0,12$ & 4,6 \\
\hline Третій день & & - & - & 12 & $50,29 \pm 0,61$ & 10,1 & 12 & $21,95 \pm 0,13$ & 4,7 \\
\hline Четвертий день & & - & - & 12 & $50,30 \pm 0,61$ & 10,1 & 12 & $22,00 \pm 0,13$ & 4,6 \\
\hline П'ятий день & & - & - & 12 & $50,31 \pm 0,61$ & 10,1 & 12 & $22,03 \pm 0,13$ & 4,7 \\
\hline
\end{tabular}

3 даної таблиці можна зазначити що жива маса збільшувалась поступово. Впродовж перших п'яти діб при насиченні киснем 8 мг/л. ЖМ червноклешневого зросла на 1,67 г, широкопалого - 0,22 г, мармурового - 0,18 г. При зниженні рівня кисню до 6 мг/л. значних змін не помічено, прирости становили відповідно 1,69 г; 0,23 г; 0,19 г.

3 десятого дня досліду при вмісті кисню 5 мл/л у раків червоноклешневого виду спостерігалося зменшення рухливості та пригнічення апетиту, на кінець другої доби експерименту $75 \%$ раків цієї групи загинуло, зважаючи на це, ми зупинили проведення досліду на червоноклешневих раках, в живих лишились тільки самці.

На кінець третьої доби симптоми кисневого голо- дування проявилися і у раків широкопалого річкового виду. Проте кубинський мармуровий рак найкраще переніс зниження рівня кисню у воді. Збільшення ЖМ спостерігалось не значне, прирости становили 0,07 г у широкопалого та 0,15 г у кубинського мармурового.

Проведені нами дослідження дозволили визначити діапазон оптимальної температури води для найбільш ефективного вирощування раків різних видів та визначити критичний рівень споживання кисню. Отримані дані необхідні для розробки біотехнічних нормативів розвитку раків в штучних умовах і розрахунку технічних параметрів циркуляційної установки для його здійснення.

Висновки. 1.Коливання температурного режиму в 
межах $19,1 \ldots 22^{\circ} \mathrm{C}$ не становили значного впливу на розвиток та апетит у раків мармурового та річкового широкопалого видів, проте у австралійських червоноклешневих раків спостерігалися зменшення апетиту, зниження реакції на корм при температурі $16,1 \ldots 19,0^{\circ} \mathrm{C}$.

2. Коливання кислотності в межах 6-8 ${ }^{\circ} \mathrm{T}$ не впливало на розвиток ракоподібних. Зміна апетиту, поведінки та приростів не спостерігалася в жодній групі.

3. Було визначено, що при зниженні рівня $\mathrm{O}_{2}$ до 5 мг/л. спостерігалося зменшення рухливості та пригнічення апетиту раків червоноклешневого виду, а на кінець другої доби це призвело до летальних наслідків. Смертність по групі становила $75 \%$. Також помічено кисневе голодування і у річкового широкопалого рака. Мармуровий рак переніс зниження рівня кисню найкраще, і відреагував не значним зменшенням приростів. Необхідно відзначити порівняно високу смертність особин, що було пов'язано не з канібалізмом, а, з відносно несприятливим умовами кисневого середовища. Все це в кінцевому підсумку призвело до мінімальної біопродуктивності.

\section{Список використаної літератури:}

1. Борисов Р.Р., Ковачева Н.П., Акмиво М.Ю., Паршин-Чудин А.В. Биология и культивирование австралийского красноклешневого рака Cherax quadricarinatus (Von Martens, 1868) Москва: ВНИРО, 2013. 48 c.

2. Lawrence C., Jones C. Cherax. In: Biology of Freshwater Crayfish. / Ed. D.M.Holdich. UK, Oxford: Blackwell Science, 2002. pp. $635-670$.

3. Xiaoxuan C., Zhixin W., Licai H. Effects of Water Temperature on Ingestion and Growth of Cherax quadricarinatus. Journal of Huazhong Agricultural.1995. (In Chinese with English Abstract).

4. Meade M.E., Doeller J.E., Kraus D.W., Wals S.A. Effects of temperature and salinity on weight gain, oxygen consumption rate, and growth efficiency in juvenile redclaw crayfish Cherax quadricarinatus. Journal of the World Aquaculture Society. 2002. Vol. 33,No. 2. pp. 188-198.

5. Сущеня Л.М. Интенсивность дыхания ракообразных. Киев: Наукова думка, 1972. 195 с.

6. Ж Жигин А.В., Арыстангалиева В.А., Тырин Д.В., Ковачева Н.П. Определение оптимальной температуры и потребления кислорода при подращивании молоди австралийского красноклешневого рака. Природообустройство. 2017. №3

C. $121-128$.

7. Boon P.I. Organic matter degradation an dnutrient regenerationin Australian fresh waters. II. Spatial and temporal variation, andrelation with environ mental conditions. 1990. Archives Hydrobiolgie, 117:405-436.

8. Carolina T., Yanina P., Laura S. Effect of long term exposure to high temperature on survival, grow than dre productive parameters of the redclaw crayfish Cherax quadricarinatus. Aquaculture. 2010. Vol. 302. pp. 49-56. 2007. 12 c.

9. Кузьмина И.А. Содержание растворенного кислорода в воде. Методические указания. НовГУ, Великий Новгород,

10. Киреевский И.Р. Рыба и раки в домашнем пруду. Москва: АСТ 2007. 463с.

11. Бродський С.Я. Фауна України. Вищі раки. Річкові раки. Київ: Наукова думка. 1981. Том 26. Вип. 3. 212 с.

12. Gutekunst J., Andriantsoa R., Falckenhayn C. Clonal genome evolution and rapid invasive spread of the marbled crayfish. Nature Ecology \& Evolution, 2018, Vol. 2, pp. 567-573.

\section{References:}

1. Borisov R.R., Kovacheva N.P., Akmivo M.YU., Parshin-Chudin A.V. (2013), Biologiya i kul'tivirovaniye avstraliyskogo krasnokleshnevogo raka Cherax quadricarinatus (Von Martens, 1868) [Biology and cultivation of Australian red claw Cherax quadricarinatus (Von Martens, 1868)], VNIRO, Moskov, 48p.

2. Lawrence C., Jones C. Cherax (2002), Biology of Freshwater Crayfish [Biolohiya prisnovodnykh rakiv], Blackwell Science, UK, Oxford, pp. 635-670.

3. Xiaoxuan C., Zhixin W., Licai H. (1995), Effects of Water Temperature on Ingestion and Growth of Cherax quadricarinatus [Vplyv temperatury vody na hodivlyu ta rist Chervonokleshnevoho raku], Huazhong, Journal of Agricultural.

4. Meade M.E., Doeller J.E., Kraus D.W., Wals S.A. (2002), Effects of temperature and salinity on weight gain, oxygen consumption rate, and growth efficiency in juvenile redclaw crayfish Cherax quadricarinatus [Vplyv temperatury ta solonosti na zbil'shennya vahy, shvydkist' spozhyvannya kysnyu ta efektyvnist' rostu molodykh chervonokleshnevuh rakiv Cherax quadricarinatus], Journal of the World Aquaculture Society, Vol. 33, No. 2. Sorrento, LA, pp. 188-198.

5. Sushchenya L.M. (1972), Intensity of respiration of crustaceans [Intensivnost dykhaniya rakoobraznykh], Naukova dumka, Kiev, 195 p.

6. Zhigin A.V., Arystangaliyeva V.A., Tyrin D.V., Kovacheva N.P. (2017), Determination of the optimum temperature and oxygen consumption in the rearing of young Australian redclaw crayfish [Opredeleniye optimal'noy temperatury i potrebleniya kisloroda pri podrashchivanii molodi avstraliyskogo krasnokleshnevogo raka], Prirodoobustroystvo.. No. 3, pp. 121-128.

7. Boon P.I. (1990), Organic matter degradation an dnutrient regenerationin Australian fresh waters. II. Spatial and temporal variation, andrelation with environ mental conditions [Dehradatsiya orhanichnykh rechovyn ta reheneratsiya dna prisnykh vod Avstraliyi. II. Prostorovi ta hodyny variatsiyi ta zv"yazok z umovamy seredovyshcha], Archives Hydrobiolgie, pp. 405-436.

8. Carolina T., Yanina P., Laura S. (2010), Effect of long term exposure to high temperature on survival, grow than dre productive parameters of the redclaw crayfish Cherax quadricarinatus [efekt tryvaloho vplyvu vysokoyi temperatury na vyzhyvannya, zrostannya, nizh produktyvni parametry chervonokleshnevoho raku], Aquaculture, Vol. 302, pp. 49-56.

9. Kuz'mina I.A. (2007), The content of dissolved oxygen in water [Soderzhaniye rastvorennogo kisloroda $v$ vode], Metodicheskiye ukazaniya, NovGU, Velikiy Novgorod, 12 p.

10. Kireyevskiy I.R. (2007), Fish and crayfish in a home pond [Ryba i raki v domashnem prudu], AST, Moskva, 463 p. 
11. Brods'kiy S.Y. (1981), Fauna of Ukraine. Higher cancers. River crayfish [Fauna Ukraiini. Vishchí raki. Ríchkoví raki], Tom 26, Vol. 3, Naukova dumka, Kiev, $212 \mathrm{p}$.

12. Gutekunst J., Andriantsoa R., Falckenhayn C. (2018), Clonal genome evolution and rapid invasive spread of the marbled crayfish [Evolyutsiya klonal'noho henomu ta shvydke invazyvne poshyrennya marmurovykh rakiv], Nature Ecology \& Evolution, Vol. 2, pp. 567-573.

Fedorovych Yelyzaveta Illivna, doctor of agricultural sciences Sciences, Professor Institute of Animal Biology NAAS,

Muzhenko Andrii Volodymyrovych, graduate student MV Zubets Institute of Breeding and Genetics NAAS,

Sliusar Mykola Viktorovych, Ph.D., Associate Professor, Polissya National University

Relationship between chemical and physical indicators of water with morphological signs of cancer of different species

The object of research was the field of aquaculture, namely the technology of growing crayfish in a closed water supply. Studies have been conducted on the effect of temperature, oxygen saturation and water acidity on the morphological characteristics of crayfish. The aim of the study was to determine the optimal level of oxygen, temperature and acidity of the environment at which the largest increases and the lowest livestock losses are observed. The technology of industrial cultivation of crayfish is still underdeveloped. Cultivation of commercial crayfish with the determination of the optimal level of oxygen is the most important element of this technology. The influence of oxygen content in the cultivation of aquatic organisms is of paramount importance. The oxygen level is closely related to the temperature in the closed water supply system. Changing the temperature regime within acceptable limits does not cause significant changes in the development of crayfish, however, increasing the temperature accordingly increases oxygen consumption and activates other metabolic processes. The following results were obtained after conducting research: the best temperature for keeping all types of crayfish is $23-25^{\circ} \mathrm{C}$. The change in acidity in the range of 6-8 $8^{\circ} \mathrm{T}$ did not affect the increase in live weight of crustaceans. Changes in appetite, behavior, and gains were not observed in any group. When the oxygen level is reduced to $5 \mathrm{mg} / \mathrm{l}$. there was an appetite suppression and a decrease in the mobility of red claw crayfish, and at the end of the second day $75 \%$ of the crayfish died. Oxygen starvation has also been observed in crayfish. Marble crayfish, which did not show a significant decrease in growth, suffered the best reduction in oxygen levels. Adverse conditions of the oxygen environment provoked a relatively high mortality of individuals. In the end, all this led to minimal bioproductivity.

Key words: crayfish, Australian red claw, Astacus astacus, marble crayfish, chemical indicators of water, aquaculture, aquatic organisms.

Дата надходження до редакції: 07.12.21 p. 